\title{
Fas-mediated apoptosis and expression of related genes in human malignant hematopoietic cells
}

\author{
Kyung-Mi Kim ${ }^{1}$, Keehyun Lee ${ }^{1,2}$, \\ Young-Sook Hong ${ }^{1}$ and Hae-Young Park ${ }^{1,3}$ \\ ${ }^{1}$ Department of Biochemistry and Medical Research Center, College
of Medicine, Ewha Womans University, Seoul 158-710, Korea
${ }^{2}$ Department of Internal Medicine, College of Medicine,
Dong-A University, Busan 602-714, Korea
${ }^{3}$ Corresponding author: Tel, +82-2-650-5726;
Fax, +82-2-2642-8285; E-mail, haeyoung @mm.ewha.ac.kr
}

Accepted 14 December 2000

Abbreviations: FasL, Fas ligand; mAb, monoclonal antibody; 7AAD, 7-amino-actinomycin D; DcR3, Decoy recpetor-3; FAP-1, Fas-associated phosphatase-1

\begin{abstract}
Fas transduces apoptotic signals upon cross-linking with the Fas ligand (FasL), which is experimentally replaced by agonistic anti-Fas monoclonal antibodies (mAb). Of eight human malignant hematopoietic cell lines (HL-60, KG-1, THP-1, K562, U937, Jurkat, IM-9, RPMI-8226) examined by flow cytometric analysis, all, except K562, were found to be positive for surface Fas antigen. However, despite surface Fas expression, the agonistic antiFas mAb (7C11) induced apoptosis in only three of seven Fas-expressing cell lines (KG-1, Jurkat and IM-9). This Fas-resistance did not correlated with high levels of mRNA either for DcR3, a decoy receptor for FasL, or for FAP-1, a Fas-associated phosphatase that can block the apoptotic function of Fas. Reverse transcriptasepolymerase chain reaction (RT-PCR) analysis did not show consistent differences in the expression of $\mathrm{Bcl}-2$ and Bax between Fas-sensitive and Fas-resistant cell lines examined. These findings indicated that the presence or absence of mRNA expression of DcR3, FAP$1, \mathrm{Bcl}-2$ and $\mathrm{Bax}$ did not always correlate with relative sensitivity to Fas-mediated apoptosis. Treatment of cells with cycloheximide converted the phenotype of resistant cell lines from Fas-resistant to Fas-sensitive, and enhanced the sensitivity of Fas-sensitive cell lines. These results suggest that the Fas-resistance is dependent on the presence of labile proteins that determine resistance to Fas-mediated apoptosis and the apoptotic machinery is already in place in Fas-resistant cell lines.
\end{abstract}

Keywords: Apoptosis, Fas, DcR3, FAP-1, Bcl-2, Bax, cycloheximide

\section{Introduction}

The cell surface Fas (CD95/APO-1) is a $45 \mathrm{kD}$ type I membrane protein, and Fas ligand (FasL) is a 37 to 40 $\mathrm{kD}$ type II membrane protein that belong to the tumor necrosis factor (TNF) receptor and ligand families (Itoh et al., 1991; Suda et al., 1993). Activation of Fas by crosslinking with agonistic antibodies or by binding with FasL resulted in apoptotic cell death in susceptible cells (Itoh et al., 1991; Takahashi et al., 1994). Fas ligand (FasL) and its receptor Fas are a set of components mediating the cytotoxicity of $\mathrm{T}$ cells and regulating immune responses, tissue development, and homeostasis (Nagata and Goldstein, 1995). Attenuation of Fas pathway may cause lymphoproliferative disorders and may accelerate autoimmune diseases, whereas excessive activation of the Fas-FasL system may contribute to pathologic tissue destruction (Nagata and Goldstein, 1995; Depraetere and Goldstein, 1997).

Recent studies have suggested that resistance to apoptosis with loss of Fas function may play an important role in the pathogenesis of several malignancies (O'Connell et al., 1996; Ungefroren et al., 1998; Von Reyher et al., 1998). In addition, finding of a decoy receptor for FasL, DcR3, was recently reported (Pitte et al., 1998). DcR3 lacking an apparent transmembrane sequence, may be secreted, rather than a membrane-associated receptor. Pitti et al. (1998) found that the DcR3 gene was amplified in approximately half of a variety of human lung tumors and adenocarcinomas and suggesting that DcR3 receptor overexpression may also occur, conferring growth advantage on tumor cells by blockade of FasL-induced cell death.

Additionally, Fas possesses a unique carboxy-terminal domain shown to be important for interactions with a protein-tyrosine phosphatase (Fas-associated phosphatase-1; FAP-1) whose expression appears to correlate with inhibition of Fas-mediated apoptosis. Introduction of FAP-1 into Fas-sensitive cells confers Fas-resistance (Sato et al., 1995). However, the correlation between Fas-resistance and FAP-1 expression was controversial (Komada et al., 1997; Ungefroren et al., 1998; Yamada et al., 1999).

Another important regulator of apoptosis is Bcl-2 family. A number of $\mathrm{Bcl}-2$ homologs have been identified, including $\mathrm{Bcl}-2$ and $\mathrm{Bcl}-\mathrm{X}_{\mathrm{L}}$, which suppress apoptosis, and Bax and $\mathrm{Bcl}-\mathrm{X}_{\mathrm{S}}$, which promote apoptosis (Korsmeyer, 1995; Adams and Cory, 1998; Lee et al., 1999). Although Bcl-2 can rescue cells from apoptosis induced by a variety of insults, the role of $\mathrm{Bcl}-2$ in protecting against Fas-mediated apoptosis and the role 
of Bax in inducing Fas-mediated apoptosis are still controversial (Debatin and Krammer, 1995; Gutierrez et al., 1999; Huang et al., 1999; Takahashi et al., 1999; Ugurel et al., 1999).

In this paper, we have examined the sensitivity to Fasmediated apoptosis, and the correlation between the sensitivity to Fas-mediated apoptosis and the expression of apoptosis-related genes, Fas, DcR3, FAP-1, $\mathrm{BCL}-2$ and Bax, in human malignant hematopoietic cells. We also examined whether protein synthesis is involved in Fas-mediated apoptosis in these cells.

\section{Materials and Methods}

\section{Cell lines and cultures}

Myeloid (HL-60, KG-1 and K562), monocytic (THP-1), histiocytic (U937), T lymphoblastic (Jurkat), mature B cell (IM-9) and plasma cell (RPMI-8226) human malignant hematopoietic cell lines (American Type Culture Collection, Rockville, MD) were suspended in RPMI 1640 medium (Biowhittaker, Walkersville, MD) supplemented with $10 \%$ heat-inactivated fetal bovine serum (Biowhittaker) and antibiotics (100 units/ml penicillin and 100 mg/ml streptomycin; Gibco BRL, Geithersburg, MD) at $37^{\circ} \mathrm{C}$ in a humidified atmosphere of $95 \%$ air and $5 \%$ $\mathrm{CO} 2$. Cell viability assessed by trypan blue dye exclusion was $>90 \%$ in all experiments.

\section{Apoptosis induction and detection}

Cells were grown in 96-well plates and treated for up to $24 \mathrm{~h}$ with $10-100 \mathrm{ng} / \mathrm{ml}$ of mouse IgM agonistic anti-Fas mAb (7C11; Immunotech, Cedex, France) or isotype control mouse IgM (DAKO, Glostrup, Denmark) and then recovered and processed for apoptotic cell detection. Briefly, the cell pellet was incubated with $20 \mu \mathrm{g} / \mathrm{ml} 7$ amino-actinomycin D (7AAD; Sigma, St. Louis, MO) for $30 \mathrm{~min}$ at $4^{\circ} \mathrm{C}$ in the dark (Schmid et al., 1994; Seoh et al., 1999). Samples were analyzed on a FACSCalibur flow cytometer (Beckton Dickinson, San Jose, CA). Ten thousand events were acquired for each analysis and data were analyzed by computer fit using CellQuest software (Beckton Dickinson).

\section{RNA extraction and RT-PCR}

Total RNA was isolated using RNAzol-B method (TelTest, Friendswood, TX) following the manufacturer's instructuions and used for RT-PCR. For RT-PCR analysis, total cellular RNA $(1 \mu \mathrm{g})$ was subjected to cDNA synthesis using avian myoblastosis virus (AMV) reverse transcriptase (Promega, Madison, WI) in the supplied buffer system and random hexamer oligonucleotides (Promega) as primer. Synthesis was performed at $42^{\circ} \mathrm{C}$ for $50 \mathrm{~min}$ and followed by denaturation of the cDNA strands at $95^{\circ} \mathrm{C}$ for $10 \mathrm{~min}$. Samples were cooled rapidly to $4^{\circ} \mathrm{C}$ and 2-4 $\mu \mathrm{l}$ was used for PCR. PCR was then performed on the cDNA product in each tube using different primer sets. Primers (Table 1) for the amplification of DcR3, FAP-1, Bcl-2, Bax and $\beta$-actin were designed according to the published sequences (Nakajima et al., 1985; Oltvai et al., 1993; Sato et al., 1995; Pitti et al., 1998). Amplification conditions for the indicated cycles were performed as follows; denaturation at $93^{\circ} \mathrm{C}$ for 30 $\mathrm{s}$, annealing at the indicated temparature for $60 \mathrm{sec}$, extension at $72^{\circ} \mathrm{C}$ for $45 \mathrm{~s}$. Extension was performed for an additional $10 \mathrm{~min}$ after completion of the indicated cycles. The efficiency of reverse transcription and the amount of RNA used in RT-PCR were verified by detection of the human $\beta$-actin mRNA. PCR products were subjected to electrophoresis on a $2 \%$ agarose gel, which was then stained with ethidium bromide and photographed under UV illumination.

\section{Detection of surface Fas by flow cytometry}

Cells were washed twice with phosphate-buffered saline (PBS) and incubated for $2 \mathrm{~h}$ on ice with murine fluorescein isothiocyanate (FITC)-conjugated mouse mAb to human Fas (DX-2; Pharmingen, San Diego, CA) or FITCconjugated mouse $\operatorname{lgG}_{1}$ (Pharmingen) as a isotype negative control at a concentration of $5 \mu \mathrm{g} / \mathrm{ml}$. After two washes with PBS, the cells were analyzed for surface Fas expression by FACSCalibur using CellQuest soft-

Table 1. Primer sets designed for PCR amplification

\begin{tabular}{|c|c|c|c|c|}
\hline Gene & Amplicon size & Primer sequences; sense/antisense & Annealing temp. & PCR cycles \\
\hline DcR3 & $306 \mathrm{bp}$ & $\begin{array}{l}\text { 5'-GCTTTCCAGGACATCTCCATCAAG-3' } \\
\text { 5'-AAGCCTCTTTCAGTGCAAGTGG-3' }\end{array}$ & $61^{\circ} \mathrm{C}$ & 35 \\
\hline FAP-1 & $607 \mathrm{bp}$ & $\begin{array}{l}\text { 5'-AGGTCTGCAGAGAAGCAAGAATAC-3' } \\
\text { 5'-GAATACGAGTGTCAGACATGG-3' }\end{array}$ & $59^{\circ} \mathrm{C}$ & 35 \\
\hline $\mathrm{Bcl}-2$ & $385 \mathrm{bp}$ & $\begin{array}{l}\text { 5'-ACTTGTGGCCCAGATAGGCACCCAG-3' } \\
\text { 5'-CGACTTCGCCGAGATGTCCAGCCAG-3' }\end{array}$ & $63^{\circ} \mathrm{C}$ & 35 \\
\hline Bax & $538 \mathrm{bp}$ & $\begin{array}{l}\text { 5'-CAGCTCTGAGCAGATCATGAAGACA-3' } \\
\text { 5'-GCCCATCTTCTTCCAGATGGTGAGC-3' }\end{array}$ & $63^{\circ} \mathrm{C}$ & 35 \\
\hline$\beta$-Actin & $675 \mathrm{bp}$ & $\begin{array}{l}\text { 5'-AAGATGACCCAGATCATGTTTGAG-3' } \\
\text { 5'-AGGAGGAGCAATGATCTTGATCTT-3' }\end{array}$ & $63^{\circ} \mathrm{C}$ & 25 \\
\hline
\end{tabular}


ware (Beckton Dickinson).

\section{Results}

\section{Expression of Fas}

Eight human malignant hematopoietic cell lines were screened for expression of cell surface Fas protein by flow cytometry. Figure 1 showed that all cell lines except K562, express cell surface Fas protein. The levels of cell surface Fas protein expression in HL-60, KG-1 and IM-9 cell lines were approximately the same as in the Jurkat cell line, and those in THP-1, U937 and RPMI8226 cell lines were lower. Jurkat cell line is known to be sensitive to Fas-mediated apoptosis (Weis et al., 1995).

\section{Sensitivity to Fas-mediated apoptosis}

To determine the capability of the cell surface Fas molecule to transduce an apoptotic signal in malignant hematopoietic cells, the ability of agonistic anti-Fas mAb (7C11) was tested for induction of apoptosis measured by 7AAD staining in flow cytometry. Fas-mediated apoptosis in cells expressing cell surface Fas protein was observed in a concentration- and time-dependent man-
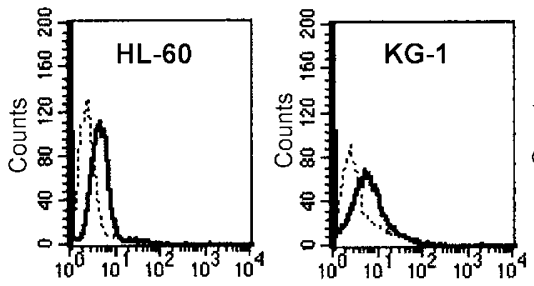

FL1-Height

FL1-Height
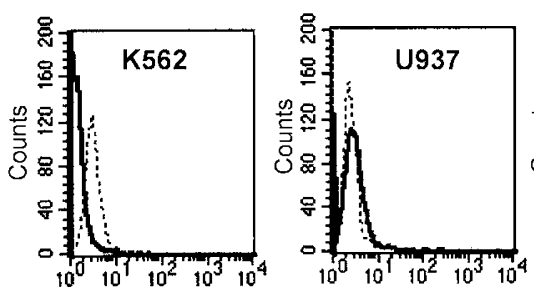

FL1-Height

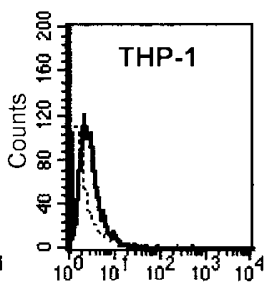

FL1-H

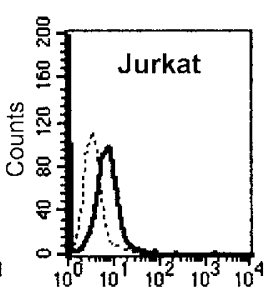

FL1-Height
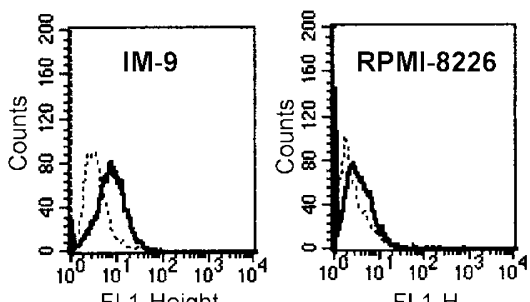

Fas-FITC

Figure 1. Expression of cell surface Fas protein analyzed by flow cytometry in human malignant hematopoietic cells. In each group, the dashed line indicates cells stained with FITC-conjugated irrelevant mouse $\operatorname{lgG}_{1}$ (as negative control), the solid line indicates positive cell stained with FITC-conjugated anti-Fas mAb (DX2).
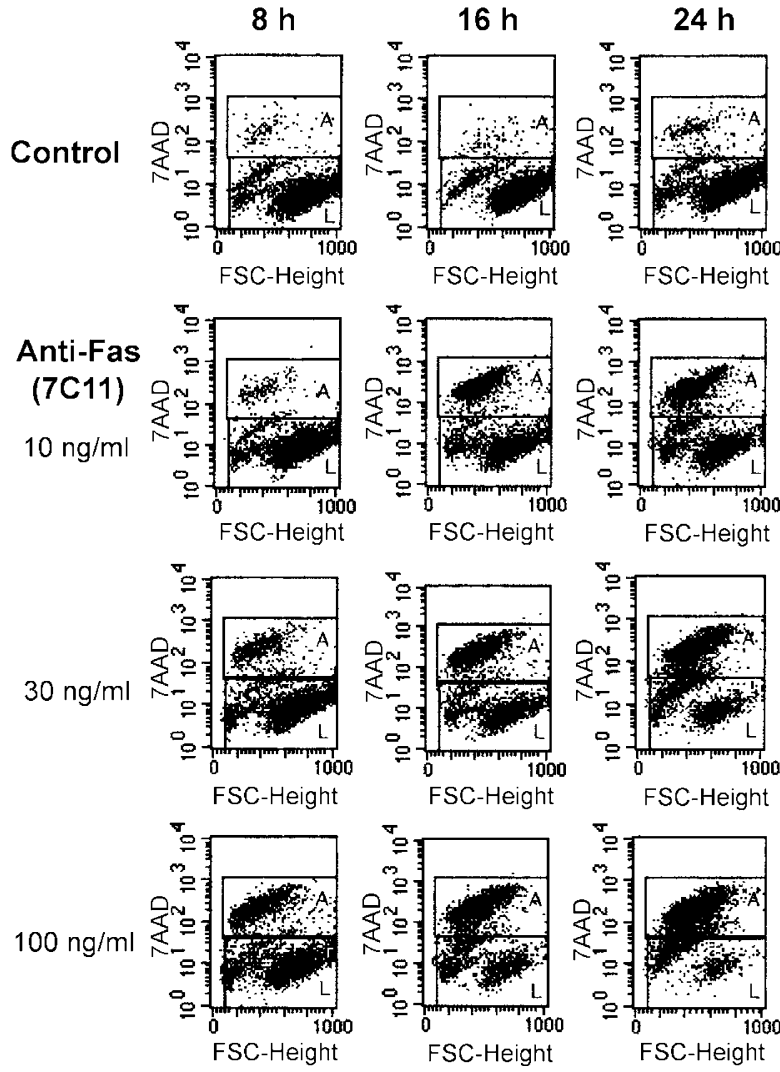

Figure 2. Fow cytometric analysis of apoptosis after treatment of IM-9 cells with agonistic anti-Fas mAb. Cells were treated with varying concentrations of agonistic anti-Fas mAb (7C11) or isotype control IgM for up to $24 \mathrm{~h}$. Fasmediated apoptosis was measured by $7 A A D$ staining in flow cytometry. Representative scattergrams are shown. L, 7AAD-negative live cells; A, 7AAD-positive apoptotic cells.

ner in KG-1, Jurkat and IM-9 cell lines, but not in HL-60, THP-1, U937 and RPMI-8226 cell lines (Figure 2 and 3). The resistant cell lines, HL-60, THP-1, U937 and RPMI8226, and cell surface Fas-negative K562 cell line did not reveal any sign of apoptotic events even after treatment with anti-Fas mAb for $24 \mathrm{~h}$. Among the four cell lines expressing cell surface Fas protein at a high level, three (KG-1, Jurkat and IM-9) were Fas-sensitive, and only one (HL-60) was Fas-resistant. Cell lines not expressing or expressing cell surface Fas protein at a low level were Fas-resistant. These data indicate that only three of the seven cell lines expressing cell surface Fas protein are sensitive to Fas-mediated apoptosis, and the Fas-mediated apoptosis was apparently correlated with the expression levels of cell surface Fas expression.

\section{Expression of DcR3 and FAP-1}

The molecular mechanisms responsible for the resistance toward Fas-mediated apoptosis are complex and not well understood at present. To test the possibility that DcR3 and FAP-1 is involved in the resistance of 

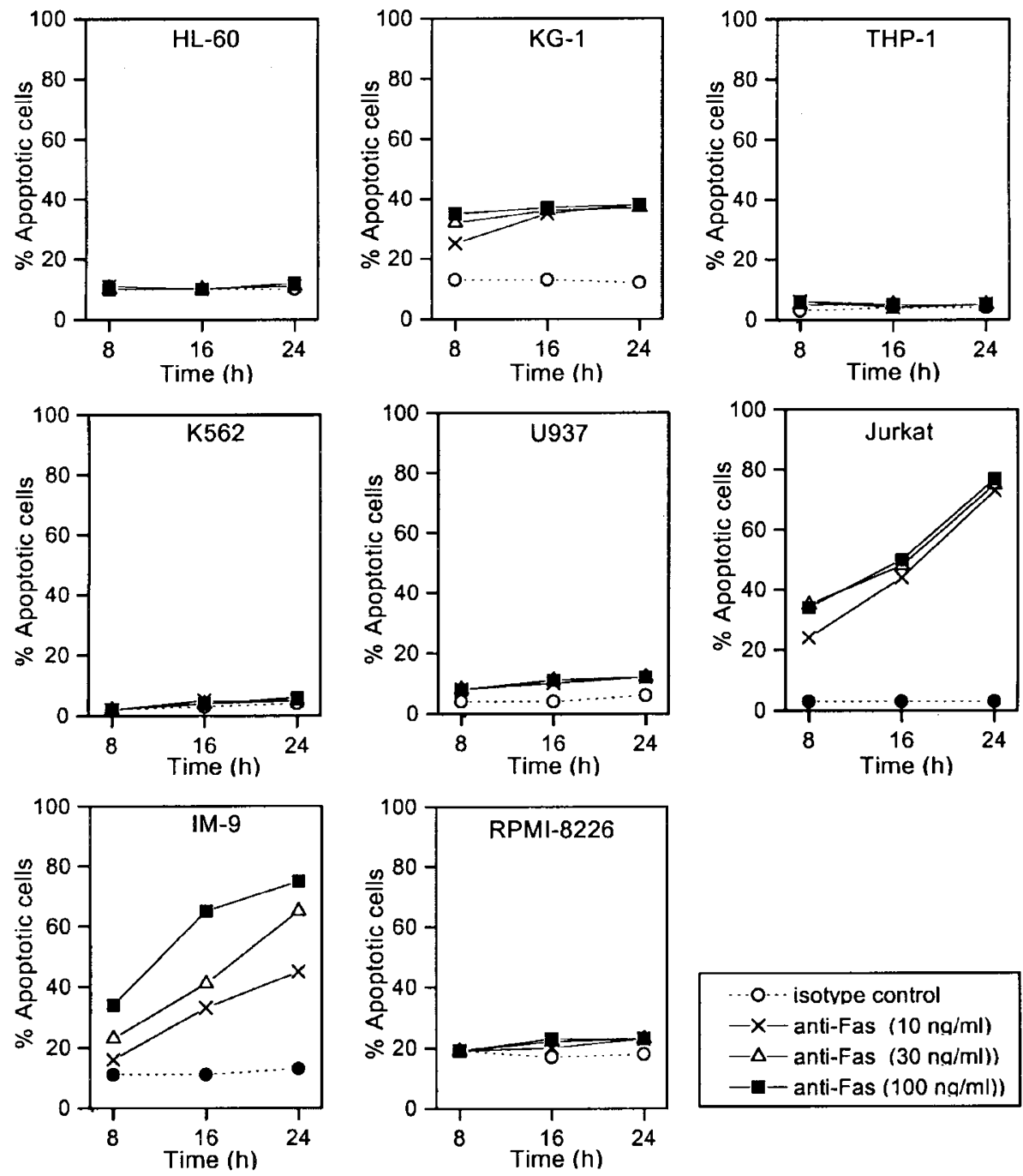

Figure 3. Concentration- and time-dependence of Fas-mediated apoptosis in human malignant hematopoietic cells. Cells were treated with varying concentrations of agonistic anti-Fas mAb (7C11) or isotype control IgM for up to $24 \mathrm{~h}$. Apoptosis was measured by 7AAD staining in flow cytometry. Data are the mean of triplicates with a standard deviation less than $10 \%$. Similar results were obtained in two independent experiments. $(\bigcirc \cdots \bigcirc)$ isotype control, $(\mathrm{X}-\mathrm{X}) 10 \mathrm{ng} / \mathrm{ml},(\triangle-\triangle) 30 \mathrm{ng} / \mathrm{ml},($

$100 \mathrm{ng} / \mathrm{ml}$ of anti-Fas mAb.

human malignant hematopoietic cells toward Fas-mediated apoptosis, we analyzed DcR3 and FAP-1 gene transcripts in these cells.

DcR3 mRNA was not detectable or barely detectable in HL-60, THP-1 and RPMI-8226 cell lines, and expression was at a moderate level in U937 and IM-9 cell lines. Of interest were the high levels of DcR3 expression in the Fas-sensitive cell lines, namely KG-1 and Jurkat, indicating that although DcR3 was present, this was apparently not inhibitory to Fas-mediated apoptosis in the examined human malignant hematopoietic cell lines. FAP-1 mRNA was expressed only in two (KG-1 and IM-9) of three Fas-sensitive cell lines, but was not expressed in other Fas-sensitive Jurkat cell line and Fas-resistant cell lines. There was no apparent correlation between the presence of FAP-1 mRNA expres- sion and the sensitivety to Fas-mediated apoptosis in the examined human malignant hematopoietic cell lines (Figure 4).

\section{Expression of $\mathrm{Bcl}-2$ and $\mathrm{Bax}$}

Susceptibility to apoptosis is modulated by the Bcl-2 family (Reed, 1994). Apoptosis is inhibited by Bcl-2 and $\mathrm{Bcl}-\mathrm{X}_{\mathrm{L}}$ but promoted by $\mathrm{Bax}$ and $\mathrm{Bcl}-\mathrm{X}_{\mathrm{S}}$. We have examined the presence of $\mathrm{Bcl}-2$ and Bax by RT-PCR in human malignant hematopoietic cell lines. RT-PCR did not reveal the presence of Bcl-2 mRNA in cell surface Fas-negative, K562, cell line. But, all of the examined seven cell lines expressing cell surface Fas, both Fas-sensitive and Fas-resistant, expressed approximately the same levels of Bcl-2 and Bax (Figure 5). There is no correlation between the mRNA expression 

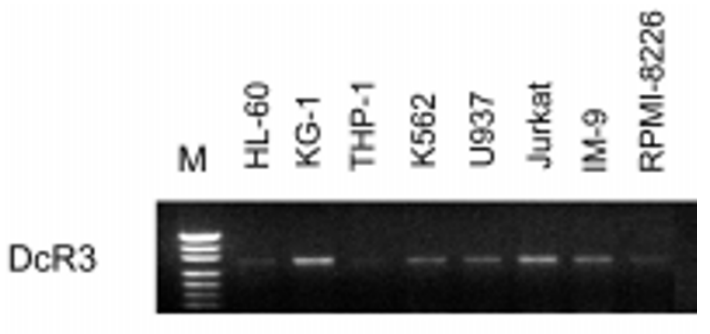

FAP-1

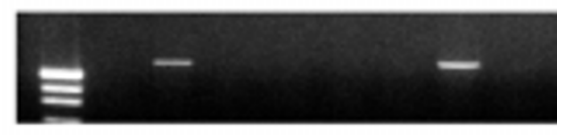

$\beta$-actin

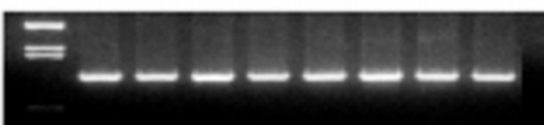

Figure 4. Expression of DcR3 and FAP-1 transcripts in human malignant hematopoietic cells by RT-PCR. The efficacy of the RT and the amount of RNA used in the RT-PCR were verified by detection of the human $\beta$-actin mRNA.

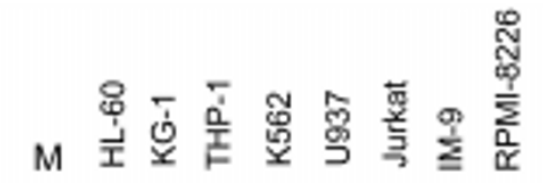

bcl-2

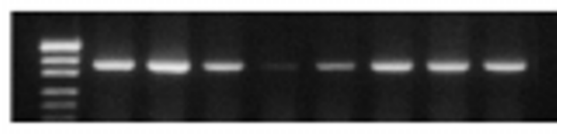

bax

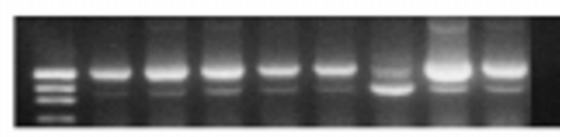

$\beta$-actin

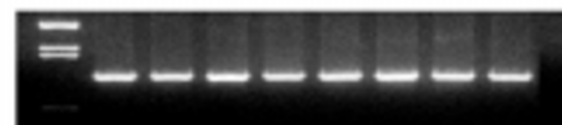

Figure 5. Expression of Bcl-2 and Bax transcripts in human malignant hematopoietic cells by RT-PCR. The efficacy of the RT and the amount of RNA used in the RT-PCR were verified by detection of the human $\beta$-actin mRNA.

of Bcl-2 and Bax and sensitivity to Fas-mediated apoptosis in the examined human malignant hematopoietic cell lines.

\section{Effect of protein synthesis inhibition on Fas-medi- ated apoptosis}

The role of protein synthesis in Fas-mediated apoptosis was tested by exposing human malignant hematopoietic cells for $24 \mathrm{~h}$ to the anti-Fas mAb (7C11) alone or in the presence of 0.1 or $1 \mu \mathrm{g} / \mathrm{ml}$ of cycloheximide. As shown in Figure 6 and 7, cycloheximide itself did not induce apoptosis or induced only low levels of apoptosis in the range of the concentrations used. Most importantly, treatment with cycloheximide converted the phenotype of
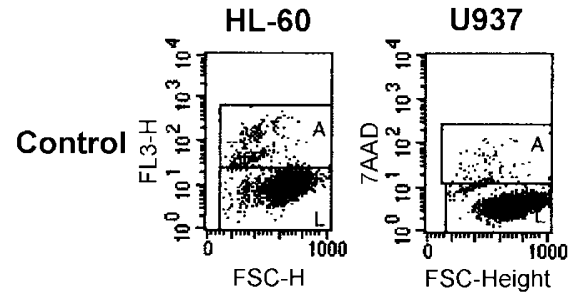

RPMI-8226

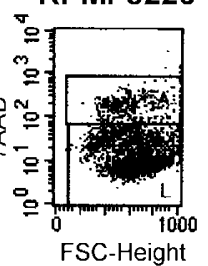

Fas
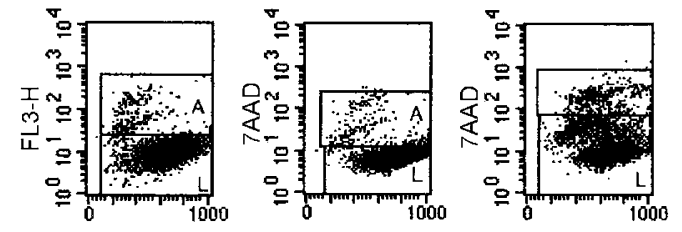

FSC-Height

FSC-Height
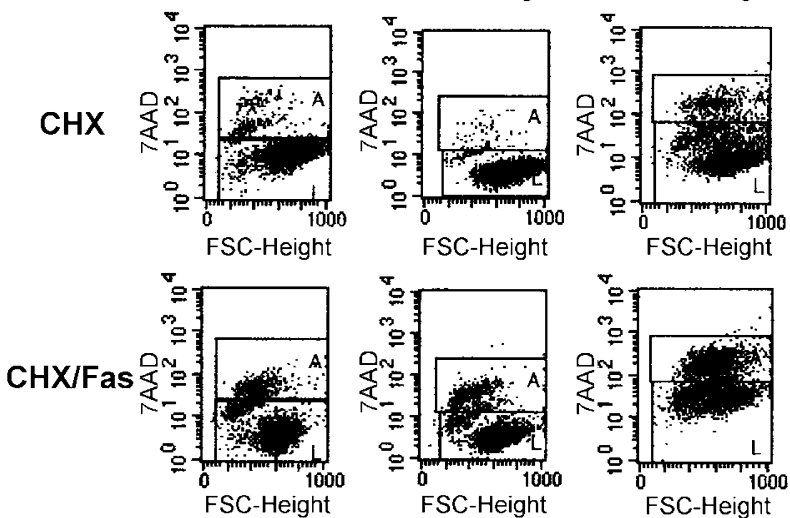

Figure 6. Sensitization of Fas-resistant cells by protein synthesis inhibitor, cycloheximide. Cycloheximide was either given alone or together with antiFas mAb (7C11). Cells were pretreated with cycloheximide $(1 \mu \mathrm{g} / \mathrm{ml}$ for $\mathrm{HL}$ $60,0.1 \mu \mathrm{g} / \mathrm{ml}$ for U937 and RPMI-8226) for $2 \mathrm{~h}$ and then treated with $30 \mathrm{ng} /$ $\mathrm{ml}$ of anti-Fas mAb for $24 \mathrm{~h}$. Fas-mediated apoptosis was then measured by 7AAD staining in flow cytometry. Representative scattergrams are shown. CHX, cycloheximide; L, 7AAD-negative live cells; A, 7AAD-positive apoptotic cells.

HL-60, U937 and RPMI-8226 from Fas-resistant to Fassensitive at a sub-toxic concentration. Pretreatment of cells with cycloheximide also increased the sensitivity to Fas-mediated apoptosis in all three Fas-sensitive cell lines (KG-1, Jurkat and IM-9). THP-1 was found to be the only cell line that remained Fas-resistant in the presence of cycloheximide although it expresses cell surface Fas protein.

The observation that the phenotype of human malignant hematopoietic cells may be converted from Fasresistant to Fas-sensitive under cycloheximide treatment suggesting that the resistance to Fas-mediated apoptosis is critically dependent on protein synthesis and that the apoptotic machinery is already in place.

\section{Discussion}

In tumors tested to date, a wide spectrum of Fas expression and sensitivity to Fas-mediated apoptosis is 

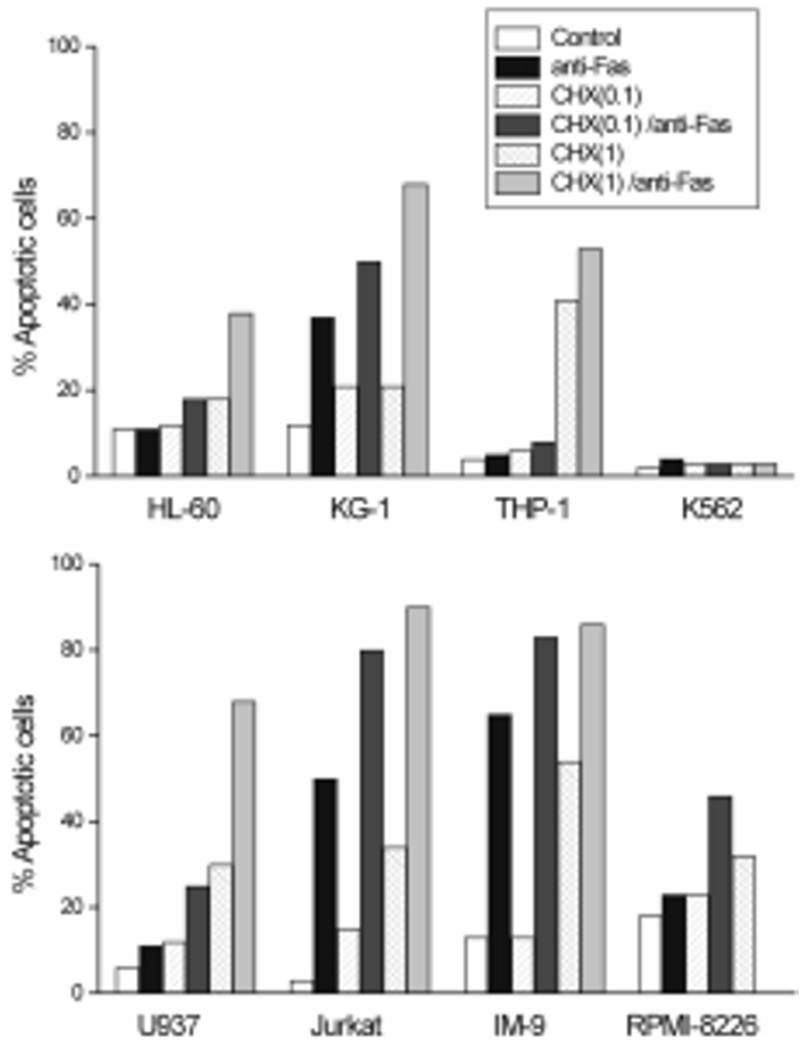

Figure 7. Effects of cycloheximide on Fas-mediated apoptosis. Cycloheximide was either given alone or together with anti-Fas mAb. Cells were pretreated with cycloheximide $(0.1$ or $1 \mu \mathrm{g} / \mathrm{ml})$ for $2 \mathrm{~h}$ and then treated with anti-Fas mAb (7C11) for $24 \mathrm{~h}$. Fas-mediated apoptosis was then measured by 7AAD staining in flow cytometry. Data are the mean of triplicates with a standard deviation less than $10 \%$. Similar results were obtained in two independent experiments.

found. This ranges from: minimal or no expression of Fas in melanoma (Leithauser et al., 1993); downregulation of Fas in hepatocellular carcinoma (Higaki et al., 1996); expression of Fas, but resistance to Fas-mediated apoptosis in colon carcinoma (Moller et al., 1994), breast carcinoma (Keane et al., 1996) and pancreatic adenocarcinoma (Ungefroren et al., 1998); to frequent sensitivity to Fas-mediated death in glioma cell lines (Weller et al., 1994). In general, Fas expression in cancer cells is downregulated and also in some cases nonfunctional. Many mechanisms for a developing resistance to apoptosis have been suggested in malignant cells including: lack of cell surface Fas protein expression; production of a soluble form of Fas, alterations in intracellular Fas-signaling pathways; synthesis of antiapoptotic proteins such as the Bcl-2 family of proteins. In our study, four of seven cell surface Fas-expressing cell lines, in which Fas was expressed at a low level, might utilize one of these mechanisms.

DcR3 is a decoy receptor for FasL and competes with Fas for FasL binding; hence it may represent a mechanism of extracellular regulation of Fas/FasL interaction
(Pitti et al, 1998). Two decoy receptors that belong to the Tumor necrosis factor (TNF) receptor family, DcR1 and DcR2, regulate the Fas-related apoptosis-inducing molecule, TNF-related apoptosis-inducing ligand (TRAIL /APO-2) (Ashikenazi and Dixit, 1998). Unlike DcR1 and DcR2, which are membrane-associated proteins, DcR3 is directly secreted into the extracellular space and function as decoys to modulate ligands that induce apoptosis. However, we could not correlate the levels of DcR3 mRNA expression with relative sensitivity to apoptosis induced by anti-Fas mAb in human malignant hematopoietic cell lines expressing cell surface Fas protein. Fas-sentive cell lines expressed DcR3 at a high level. Similar results with regard to other decoy receptors were reported. Cells expressing TRAIL-R2 were sensitive to TRAIL-induced apoptosis, regardless of the presence or absence of TRAIL-R3 (DcR1) and/or TRAILR4 (DcR2), decoy receptors for TRAIL in melanoma (Griffith et al., 1999) and brain tumors (Frank et al., 1999).

FAP-1 has been identified as a protein tyrosine phosphatase capable of interacting with the cytosolic negative regulatory domain of the receptor and is proposed to inhibit Fas signaling and, subsequently, Fas-induced apoptosis (Sato et al., 1995). However, the correlation between Fas-resistance and FAP-1 expression was controversial (Komada et al., 1997; Yamada et al., 1999). The resistance to Fas-mediated apoptosis was found to be associated with high levels of FAP-1 mRNA in pancreatic tumor cells (Ungefroren et al., 1998). Whereas, the levels of FAP-1 mRNA expression did not always correlate with the sensitivity to Fas-mediated growth inhibition in colon carcinoma cells (Houghton et al., 1997) and leukaemia/lymphoma cell lines (Komada et al., 1997). In our study, FAP-1 mRNA was detected only in two Fas-sensitive cell lines, KG-1 and IM-9, whereas Fas-resistant cell lines was completely negative for FAP-1 mRNA. Other factors independent of FAP-1 also known to influence Fas signaling in human malignant hematopoietic cells.

The Bcl-2 family consists of several members that are homologous to each other but have opposing effects on cell death (Admas and Cory, 1998). Bcl-2 and Bcl- $\mathrm{X}_{\mathrm{L}}$ are known to be death repressors, whereas $\mathrm{Bax}$ and $\mathrm{Bcl}-\mathrm{X}_{\mathrm{S}}$ are death promoters. It was reported that $\mathrm{Bcl}-2$ and $\mathrm{Bax}$ were also important for regulating Fas-induced apoptosis in Burkitt's lymphoma (Gutierrez et al., 1999), melanoma (Ugurel et al., 1999) and hepatoma (Takahashi et al., 1999). However, others reported that Bcl-2 and Bcl$X_{L}$ did not block Fas-mediated apoptosis in lymphocytes and hepatocytes (Huang et al., 1999), and Fas-mediated apoptosis in T-ALL was independent of the amount of Bcl-2. In our study, Both Fas-sensitive and Fasresistant cell lines expressed approximately the same levels of Bcl-2 and Bax mRNA and the sensitivity to Fas-mediated apoptosis did not correlated with the 
levels of mRNA expressions of Bcl-2 and Bax. But the fact that mRNA expression is not necessarily followed by translation into protein has to be taken into account.

Fas resistance could overcome by cycloheximide in some Fas-resistant cell lines examined (HL-60, U937 and RPMI-8226). Based on the present study, an shortlived apoptosis-inhibitory protein or proteins might be the reason for the deficient functioning of the Fas system in those cells, since the exposure of those cells to cycloheximide broke resistance to Fas-mediated apoptosis in the presence of an agonistic anti-Fas antibody. Inhibition of short lived apoptosis-inhibitory proteins by cycloheximide could change the ratio of pro-apoptotic and anti-apoptotic program. Another possibility for the effect of cycloheximide would be its direct function as a co-stimulatory signal with an agonistic anti-Fas antibody in inducing apoptosis as previously speculated (Natoli et al., 1995). However, in that case also sub-inhibitory concentrations of cycloheximide would have been expected to convert Fas-resistant cells to Fas-sensitive ones. Furthermore, the opposite effects of cycloheximide on cells inducing apoptosis by different apoptotic stimuli in the same cells were reported; the sensitizing effect on Fas-mediated apoptosis vs the blocking effect on B cell receptor-induced apoptosis in human B lymphocytes (Graves et al., 1998), and the sensitizing effect on Fas-mediated apoptosis vs the blocking effect on etoposide-induced apoptosis in human acute myeloblastic leukemia cells (Siitonen et al., 2000). These conflicting reports suggest that the effects of cycloheximide may depend on cell type and apoptotic stimulus. We have no information yet as to which protein is able to induce the inactivation of the Fas system in those Fasresistant cell lines but there are many possibilities as has previously been suggested (Schulze-Osthoff et al., 1998). Recently some of the short-lived anti-apoptotic proteins, such as FLIP (FLICE-inhibitory proteins), RIP, XIAP and clAP2 (IAP; inhibitors of apoptosis proteins) have been reported as regulatory proteins for the sensitizing effect of cycloheximide to Fas-mediated apoptosis in several different cells (Fulda et al., 2000; Wajant et al., 2000; Willems et al., 2000).

An understanding of the basis for resistance to apoptosis will provide valuable information about mechanisms that determine the resistance of human malignant hematopoietic cells to chemotherapeutic treatment. The results presented here suggest that the intrinsic propensity to undergo Fas-mediated apoptosis could be utilized for a target for therapeutic intervention.

\section{Acknowledgement}

This research was supported in part by the Korea Science and Engineering Foundation (KOSEF) through the Center for Cell Signaling Research (CCSR) at Ewha Womans University and in part by the MOST through National Research Program (00-N6-01-01-A-05) for Women's University.

\section{References}

Adams, J. M. and Cory, S. (1998) The Bcl-2 protein family: Arbiters of cell survival. Science 281: 1322-1326

Ashikenazi, A. and Dixit, V. M. (1998) Death receptors: signaling and modulation. Science 281: 1305-1308

Debatin, K. M. and Krammer, P. H. (1995) Resistance to APO1 (CD95)-induced apoptosis in T-ALL is determined by a Bcl2 independent antiapoptotic program. Leukemia 9: 815-820

Depraetere, V. and Goldstein, P. (1997) Fas and other cell death signaling pathways. Sem. Immunol. 9: 93-107

Frank, S., Kohler, U., Schackert, G. and Schackert, H. K. (1999) Expression of TRAIL and its receptors in human brain tumors. Biochem. Biophys. Res. Comm. 257: 454-459

Fulda, S., Meyer, E. and Debatin, K. M. (2000) Metabolic inhibitors sensitize for CD95(APO-1/Fas)-induced apoptosis by down-regulating Fas-associated death domain-like interleukin 1-converting enzyme inhibitory protein expression. Cancer Res. 60: 3947-3956

Graves, J. D., Draves, K. E., Craxton, A., Krebs, E. G. and Clark, E. A. (1998) A comparison of signaling requirements for apoptosis of human B lymphocytes induced by the B cell receptor and CD95/Fas. J. Immunol. 161: 168-174

Griffith, T. S., Rauch, C. T., Smolak, P. J., Waugh, J. Y., Boiani, N., Lynch, D. H., Smith, C. A., Goodwin, R. G. And Kubin, M. Z. (1999) Functional analysis of TRAIL receptors using monoclonal antibodies. J. Immunol. 162: 2597-2605

Gutierrez, M. I., Cherney, B., Hussain, A., Mostowski, H., Tosato, G., Magrath, I. and Bhatia, K. (1999) Bax is frequently compromised in Burkitt's lymphomas with irreversible resistance to Fas-induced apoptosis. Cancer Res. 59: 696-703

Higaki, K., Yano, H. and Kojiro, M. (1996) Fas antigen expression and its relationship with apoptosis in human hepatocellular carcinoma and noncancerous tissues. Am. J. Pathol. 149: $429-437$

Houghton, J. A., Harwood, F. G., Gibson, A. and Tillman, D. M. (1997) The Fas signaling pathway is functional in colon carcinoma cells and induces apoptosis. Clin. Cancer Res. 3: 2205-2209

Huang, D. C., Hahne, M., Schroeter, M., Frei, K., Fontana, A., Villunger, A., Newton, K., Tschopp, J. and Strasser, A. (1999) Activation of Fas by FasL induces apoptosis by a mechanism cannot be blocked by Bcl-2 or Bcl-XL. Proc. Natl. Acad. Sci. USA. 96: 14871-14876

Itoh, N., Yonehara, S., Ishii, A., Yonehara, M., Mizushima, S. I., Sameshima, M., Hase, A., Seto, Y. and Nagata, S. (1991) The polypeptide encoded by the cDNA for human cell surface antigen Fas can mediate apoptosis. Cell 66: 233-243 
Keane, M. M., Ettenberg, S. A., Lowrey, G. A., Russell, E. K. and Lipkowitz, S. (1996) Fas expression and function in normal and malignant breast cell lines. Cancer Res. 56: 47914798

Komada, Y., Inaba, H., Zhou, Y. W., Zhang, X. L., Tanaka, S., Azuma, E. and Sakurai, M. (1997) mRNA expression of Fas receptor (CD95)-associated proteins (Fas-associated phosphatase-1/FAP-1, Fas-associating protein with death domain/ FADD, and receptor-interacting protein/RIP) in human leukaemia/ lymphoma cell lines. Br. J. Haematol. 99: 325-330

Korsmeyer, S. J. (1995) Regulators of cell death. Trends Genet. 11: 101-105

Lee, J., Park, B. J., Park, J. H., Yang, M. H. and Chi, S. G. (1999) TGF-1 inhibition of apoptosis through the transcriptional up-regulation of $\mathrm{Bcl}-\mathrm{X}_{\mathrm{L}}$ in human monocyte leukemia U937. Exp. Mol. Med. 31: 126-133

Leithauser, F., Dhein, J., Mechtersheimer, G., Koretz, K., Bruderlein, S., Henne, C., Schmidt, A., Debatin, K. M., Krammer, P. H. and Moller, P. (1993) Constitutive and induced expression of APO-1, a new member of the nerve growth factor/tumor necrosis factor receptor superfamily, in normal and neoplastic cells. Lab. Invest. 69: 415-429

Moller, P., Koretz, K., Leithauser, F., Bruderlein, S., Henne, C., Quentmeier, A. and Krammer, P. H. (1994) Expression of APO-1 (CD95), a member of the NGF/TNF receptor superfamily, in normal and neoplastic colon epithelium. Int. J. Cancer 57: 371-377

Nagata, S., and Goldstein, P. (1995) Fas death factor. Science 1995: 267: 1449-1456

Nakajima-lijima, S., Hamada, H., Reddy, P. and Kakunaya, T. (1985) Molecular structure of the human cytoplasmic -actin gene: interspecies homology of sequence in the introns. Proc. Natl. Acad. Sci. USA 82: 6133-6137

Natoli, G., Ianni, A., Costanzo, A., De Petrillo, G., Ilari, I., Chiriool, P., Balsano, C. and Levrero, M. (1995) Resistance to Fas-mediated apoptosis in human hepatoma cells. Oncogene 11: 1157-1162

O'Connell, J., O'Sullivan, G. C., Collins, J. K., Shanahan, F. (1996) The Fas counterattack: Fas-mediated T cell killing by colon cancer cells expressing Fas ligand. J. Exp. Med. 184: 1075-1082

Oltvai, Z. N., Milliman, C. L. and Korsmeyer, S. J. (1993) Bcl2 heterodimerizes in vivo with a conserved homolog, Bax, that accelerates pragrammed cell death. Cell 74: 609-619

Pitti, R. M., Marsters, S. A., Lawrence, D. A., Roy, M., Kischkel, F. C., Dowd, P., Huang, A., Donahue, C., Sherwood, S. W., Baldwin, D. T., Godowski, P. J., Wood, W. I., Gurney, A. L., Hillan, K., Cohen, R., Goddard, A. D., Botstein, D. and Ashkenazi, A. (1998) Genomic amplification of a decoy receptor for Fas ligand in lung and colon cancer. Nature 396: 699-702

Reed, J. C. (1994) Bcl-2 and the regulation of programmed cell death. J. Cell Biol. 124: 1-6

Sato, T., Irie, S., Kitada, S. and Reed, J. C. (1995) FAP-1: a protein tyrosine phosphatase that associates with Fas.

\section{Science 268: 411-415}

Schmid, I., Uittenbogaart, C. H., Keld, B., Giorgi, J. V. (1994) A rapid method for measuring apoptosis and dual-color immunofluorescence by single laser flow cytometry. J. Immunol. Methods 170: 145-157

Schulze-Osthoff, K., Ferrari, D., Los, M., Wesselborg, S. and Peter, M. E. (1998) Apoptosis signaling by death receptors. Eur. J. Biochem. 254: 439-459

Seoh, J. Y., Woo, S. Y., Im, S. A., Kim, Y. J., Park, H. Y., Lee, S., Lee, M. A., Yoo, E. S., Chung, W. S. and Seong, C. M. (1999) Distinct patterns of apoptosis in association with modulation of CD44 induced by thrombopoietin and granulocyte-colony stimulating factor during ex vivo expansion of human cord blood CD34+ cells. Br. J. Haematol. 107: 185-194

Siitonen, T., Mantymaa, P., Saily, M., Savolainen, E. R. and Koistinen, P. (2000) Etoposide-induced apoptosis is not associated with the Fas pathway in acute myeloblastic leukemia cells. Leukemia Res. 24: 282-288

Suda, T., Takahashi, T., Goldstein, P. and Nagata, S. (1993) Molecular cloning and expression of the Fas ligand, a novel member of the tumor necrosis factor family. Cell 75: 11691178

Takahashi, M., Saito, H., Okuyama, T., Miyashita, T., Kosuga, M., Sumisa, F., Yamada, M., Ebinuma, H. and Ishii, H. (1999) Overexpression of $\mathrm{Bcl}-2$ protects humsn hepatoma cells from Fas-antibody-mediated apoptosis. J. Hepatol. 31: 315-322

Takahashi, T., Tanaka, M., Inazawa, J., Abe T., Suda, T. and Nagata, S. (1994) Human Fas ligand: gene structure, chromosomal location and species specificity. Intl. Immunol. 6: 15671574

Tsujimoto, Y. and Croce, C. M. (1986) Analysis of the structure, transcripts, and protein products of bcl-2, the gene involved in human follicular lymphoma. Proc. Natl. Acad. Sci. USA 83: 5214-5218

Ugurel, S., Seiter, S., Rappl, G., Stark, A., Tilgen, W. and Reinhold, U. (1999) Heterogenous susceptibility to CD95induced apoptosis in melanoma cells correlates with bcl-2 and bcl-x expression and is sensitive to modulation by interferon\%. Intl. J. Cancer 82: 727-736

Ungefroren, H., Voss, M., Jansen, M., Roeder, C., HenneBruns, D., Kremer, B. and Kalthoff, H. (1998) Human pancreatic adenocarcinomas express Fas and Fas ligand yet are resistant to Fas-mediated apoptosis. Cancer Res. 58: 17411749

Von Reyher, U., Strater, J., Kettstein, W., Gschwendt, M, Krammer, P. H. and Moller, P. (1998) Colon carcinoma cells use different mechanismss to escape CD95-mediated apoptosis. Cancer Res. 58: 526-534

Wajant, H., Haas, E., Schwenzer, R., Muhlenbeck, F., Kreuz, S., Schubert, G., Grell, M., Smith, C. and Scheurich, P. (2000) Inhibition of death receptor-mediated gene induction by a cycloheximide-sensitive factor occurs at the level of or upstream of Fas-associated death comain protein (FADD). J. Biol. Chem. 275: 24357-24366

Weis, M., Schlegel, J., Kass, G. E., Holmstrom, T. H., Peters, 
I., Eriksson, J., Orrenius, S. and Chow, S. C. (1995) Cellular events in Fas/APO-1-mediated apoptosis in JURKAT T lymphocytes. Exp. Cell Res. 219: 699-708

Weller, M., Frei, K., Groscurth, P., Krammer, P. H., Yonekawa, Y. and Fontana, A. (1994) Anti-Fas/APO-1 antibody-mediated apoptosis of cultured human glioma cells. Induction and modulation of sensitivity by cytokines. J. Clin. Invest. 94: 954964

Willems, F., Amraoui, Z., Nathalie, V., Verhasselt, V., Aksoy,
E., Scaffidi, C., Peter, M. E., Krammer, P. H. and Goldman, M. (2000) Expression of C-FLIP $L$ and resistance to CD95-mediated apoptosis of monocyte-derived dendritic cells: inhibition by bisindolylmaleimide. Blood 95: 3478-3482

Yamada, Y., Sugahara, K., Tsuruda, K., Nohda, K., Hata, T., Maeda, T., Honda, M., Tawara, M., Hayashibara, T., Joh, T., Tomonaga, M., Miyazaki, Y. and Kamihira, S. (1999) Fasresistance in ATL cell lines not associated with HTLV-I or FAP1 production. Cancer Lett. 147: 215-219 